\title{
NGHIÊN CỬU CÁC ĐẶC ĐIỂM LÂM SÀNG, CẬN LÂM SÀNG CỦA BỆNH LÝ KÉN KHÍ PHỔI
}

Châu Phú Thi ${ }^{*}$, Lê Nũ Hòa Hiệp ${ }^{* *}$, Nguyên Văn Khôi ${ }^{*}$

\section{TÓM TẮT}

Có 103 trường hợp được điều trị ngoại khoa xử trí kén khí phổi, trong đó có 67 trường hợp kén khí đơn thuần và 36 trường hợp kén khí kèm khí phế thũng. Đau ngực chiếm tỉ lệ 95,1\% cho cả hai nhóm nghiên cứu, kế tiếp là khó thở chiếm $89,3 \%$, ho đàm chiếm $34 \%$, ít nhất là ho khạc máu có tỉ lệ 1\%. Chỉ số FEV1 trong khoảng 50\% đến $80 \%$ so tiên đoán chiếm $52,9 \%$, ở mức $30 \%$ đến $50 \%$ so tiên đoán chiếm $35,3 \%$. Còn lại trên $80 \%$ so tiên đoán chiếm $11,8 \%$.

Tù khóa: bệnh kén khí phổi, khí phế thũng, triệu chứng lâm sàng

\section{SUMMARY}

There were 103 patients in our study, 67 cases group I and 36 cases group II. Chest pain was $95,1 \%$, dyspnea was $89,3 \%$, chronic coughwas $34 \%$ and hemotypsis was $1 \%$. Functional measures were FEV1(forced expiratory volume in 1 second) (\% predicted), $50 \%<$ FEV $1<80 \%$ has $52,9 \% ; 30 \%<\mathrm{FEV} 1<50 \%$ has $35,3 \%$; FEV $1>80 \%$ has $11,8 \%$.

Key words: bullous disease of the lung, emphysema, clinical symptom

\section{I. ĐẶT VẤN ĐỀ}

Kén khí phổi là những khoảng chứa khí khu trú nằm ở bề mặt hoặc bên trong nhu mô phổi, có kích thước trên $1 \mathrm{~cm}$ đường kính và có thể xuất hiện ở một bên hoặc cả hai bên phổi. [3],[6],[9]

Kén khí phổi khi mới xuất hiện, có kích thước nhỏ chưa ảnh hưởng gì đến sức khoẻ và đời sống của người bệnh. Khi kén khí phát triển kích thước hoặc khi xuất hiện những biến chứng người bệnh sẽ có những biểu hiện lâm sàng [4],[5],[8]

Nhiều tác giả trên thế giới đã tìm hiểu những đặc điểm lâm sàng của bệnh kén khí. Thế nhưng, những mô tả về biểu hiện lâm sàng còn có nhiều đặc điểm khác nhau trong các nghiên cứu.Mặt khác, nhóm bệnh kén khí đơn thuần và nhóm có kèm khí phế thũng có những biểu hiện lâm sàng khác nhau. [2],[7],[11]

Vì vậy, chúng tôi tiến hành nghiên cứu về đặc điểm lâm sàng và cận lâm sàng cho các trường hợp kén khí phổi được phẫu thuật tại bệnh viện chúng tôi với các mục tiêu sau:

1. Nghiên cứu các đặc điểm lâm sàng của hai nhóm bệnh kén khí phổi.

2. Đánh giá ảnh hưởng của bệnh lý kén khí phổi đến sức khỏe người bệnh qua các kết quả cận lâm sàng.

\section{PHƯƠNG PHÁP NGHIÊN CÚU}

\subsection{Thiết kế nghiên cứu:}

Nghiên cứu mô tả loạt ca.

\subsection{Thời gian, địa điểm:}

Nghiên cứu tiến hành từ tháng $1 / 2012$ đến 12/2014 tại khoa ngoại Lồng Ngực bệnh viện Chợ Rẫy

\subsection{Tiêu chuẩn chọn bệnh:}

Các trường hợp được chẩn đoán kén khí phổi và được phẫu thuật.

\subsection{Tiêu chuẩn loại trừ}

- Những trường hợp được chẩn đoán kén khí phổi nhưng có những yếu tố chống chỉ định

- Những trường hợp kén khí phổi phát hiện khi phẫu thuật các bệnh lý khác như ung thư phổi, u nấm phổi...

\footnotetext{
* Bệnh viện Chơ Rẫy Thành phố HCM

** Bộ môn Ngoại Lồng Ngưc Tim Mạch ĐHYD TP HCM Nguoòi chịu trách nhiệm khoa họ: PGS.TS Lê Nũ Thị Hòa Hiệp Ngày nhận bài: 10/02/2017 - Ngày Cho Phép Đăng: 10/03/2017 Phản Biện Khoa hoc: PGS.TS. Đặng Ngọc Hùng GS.TS. Lê Ngọc Thành
} 
III. KẾT QUẢ

Trong thời gian nghiên cứu tiến hành tại bệnh viện Chợ Rẫy từ tháng 1/2012 đến tháng 12 / 2014, có 103 trường hợp được điều trị ngoại khoa xử trí kén khí phổi tại khoa Ngoại Lồng ngực, chúng tôi chia làm 2 nhóm bệnh: nhóm bệnh kén khí đơn thuần và nhóm bệnh kén khí có kèm khí phế thũng.

Bảng 1: Đặc điểm tuổi, giới, tiền sủ nhóm nghiên cưu

\begin{tabular}{llll}
\hline \multicolumn{1}{c}{ Đặc điểm } & $\begin{array}{c}\text { Kén khí đơn } \\
\text { thuần } \\
(\mathbf{n = 6 7 )}\end{array}$ & $\begin{array}{c}\text { Kén khí kèm } \\
\text { KPT } \\
(\mathbf{n = 3 6 )}\end{array}$ & $\begin{array}{c}\text { Cả 2 nhóm } \\
(\mathbf{n = 1 0 3 )}\end{array}$ \\
\hline $\begin{array}{l}\text { Giới tính } \\
\text { Nam }\end{array}$ & $54(80,6 \%)$ & $32(88,9 \%)$ & $86(83,5 \%)$ \\
Nữ & $13(19,4 \%)$ & $4(11,1 \%)$ & $17(16,5 \%)$ \\
\hline Tuổi trung bình & $38,3 \pm 16,3$ & $57,1 \pm 10,9$ & $44,8 \pm 17,2$ \\
\hline Tiền sử bệnh & & & \\
COPD & $0(0,0 \%)$ & $26(72,2 \%)$ & $26(25,2 \%)$ \\
Tràn khí màng phổi & $18(26,9 \%)$ & $11(30,6 \%)$ & $29(28,2 \%)$ \\
Lao phổi & $1(1,5 \%)$ & $5(13,9 \%)$ & $6(5,8 \%)$ \\
Hút thuốc lá & $32(47,8 \%)$ & $28(77,8 \%)$ & $60(58,3 \%)$ \\
$<10$ gói/năm & $18(26,9 \%)$ & $3(8,3 \%)$ & $21(20,4 \%)$ \\
$\geq 10$ gói/năm & $11(16,4 \%)$ & $24(66,7 \%)$ & $35(34,0 \%)$ \\
Đã bỏ hút thuốc lá & $3(4,5 \%)$ & $1(2,8 \%)$ & $4(3,9 \%)$ \\
Bệnh tim mạch & $2(3,0 \%)$ & $2(5,6 \%)$ & $4(3,9 \%)$ \\
Bệnh tiểu đường & $0(0,0 \%)$ & $2(5,6 \%)$ & $2(1,9 \%)$ \\
\hline
\end{tabular}

Bảng 2: Đặc điểm lâm sàng

\begin{tabular}{lccc}
\hline \multicolumn{1}{c}{ Đặc điểm } & $\begin{array}{c}\text { Kén khí đơn thuần } \\
(\mathbf{n = 6 7 )}\end{array}$ & $\begin{array}{c}\text { Kén khí kèm KPT } \\
(\mathbf{n = 3 6})\end{array}$ & $\begin{array}{c}\text { Cả 2 nhóm } \\
(\mathbf{n = 1 0 3})\end{array}$ \\
\hline Triệu chứng $L S$ & & $0(0,0 \%)$ & $1(1,0 \%)$ \\
Ho ra máu & $1(1,5 \%)$ & $34(94,4 \%)$ & $98(95,1 \%)$ \\
Đau ngực & $64(95,6 \%)$ & $34(94,4 \%)$ & $94(91,2 \%)$ \\
Đau ngực ít & $60(89,5 \%)$ & $0(0 \%)$ & $4(3,8 \%)$ \\
Đau ngực nhiều & $4(5,9 \%)$ & $36(100 \%)$ & $92(89,3 \%)$ \\
Khó thở & $56(83,5 \%)$ & $28(77,8 \%)$ & $35(34,0 \%)$ \\
Ho đàm & $7(10,5 \%)$ & $26(72,2 \%)$ & $67(65,0 \%)$ \\
Đang DL MP & $41(61,2 \%)$ & & \\
\hline
\end{tabular}




\begin{tabular}{llll}
\hline \multicolumn{2}{c}{ Múc độ khó thơ theo $m M R C$} & \\
0 điểm & $11(16,5 \%)$ & $0(0,0 \%)$ & $11(9,7 \%)$ \\
1 điểm & $48(71,6 \%)$ & $19(52,8 \%)$ & $67(65,0 \%)$ \\
2 điểm & $8(11,9 \%)$ & $17(47,2 \%)$ & $25(24,3 \%)$ \\
3 điểm & $0(0,0 \%)$ & $0(0,0 \%)$ & $0(0,0 \%)$ \\
4 điểm & $0(0,0 \%)$ & $0(0,0 \%)$ & $0(0,0 \%)$ \\
\hline
\end{tabular}

Bảng 3: Đặc điểm chức năng thông khí

\begin{tabular}{cccc}
\hline Đặc điểm & $\begin{array}{c}\text { Kén khí đơn thuần } \\
(\mathbf{n = 2 4})\end{array}$ & $\begin{array}{c}\text { Kén khí kèm } \\
\text { KPT } \\
(\mathbf{n = 1 0})\end{array}$ & $\begin{array}{c}\text { Cả 2 nhóm } \\
(\mathbf{n = 3 4 )}\end{array}$ \\
\hline FEV1 & & & \\
$\geq 80 \%$ & $4(16,7 \%)$ & $0(0,0 \%)$ & $4(11,8 \%)$ \\
$50 \%<$ FEV1 <80\% & $14(58,3 \%)$ & $4(40,0 \%)$ & $18(52,9 \%)$ \\
$30 \%<$ FEV1 <50\% & $6(25 \%)$ & $6(60,0 \%)$ & $12(35,3 \%)$ \\
$<30 \%$ & $0(0,0 \%)$ & $0(0,0 \%)$ & $0(0,0 \%)$ \\
\hline FEV1/FVC & & & \\
$\geq 70 \%$ & $23(95,8 \%)$ & $2(20 \%)$ & $25(73,5 \%)$ \\
$<70 \%$ & $1(4,2 \%)$ & $8(80 \%)$ & $9(26,5 \%)$ \\
\hline
\end{tabular}

Bảng 4: Đặc điểm khí máu động mạch

\begin{tabular}{cccc}
\hline Đặc điểm & $\begin{array}{c}\text { Kén khí đơn thuần } \\
(\mathbf{n = 4 1})\end{array}$ & $\begin{array}{c}\text { Kén khí kèm KPT } \\
(\mathbf{n = 2 8})\end{array}$ & $\begin{array}{c}\text { Cả 2 nhóm } \\
(\mathbf{n = 6 9})\end{array}$ \\
\hline PaO2 (mmHg) & & & \\
$\geq 80$ & $20(48,8 \%)$ & $5(17,9 \%)$ & $25(36,2 \%)$ \\
$60-79$ & $16(39,0 \%)$ & $18(64,3 \%)$ & $34(49,3 \%)$ \\
$40-59$ & $5(12,2 \%)$ & $5(17,9 \%)$ & $10(14,5 \%)$ \\
$<40$ & $0(0,0 \%)$ & $0(0,0 \%)$ & $0(0,0 \%)$ \\
\hline Các thông số KMĐM & & & \\
$\mathrm{pH}$ & $7,42 \pm 0,03$ & $7,43 \pm 0,05$ & $7,42 \pm 0,04$ \\
$\mathrm{PaO} 2(\mathrm{mmHg})$ & $82,6 \pm 30,8$ & $74,6 \pm 18,0$ & $79,7 \pm 27,2$ \\
$\mathrm{PaCO} 2(\mathrm{mmHg})$ & $40,6 \pm 4,3$ & $38,7 \pm 6,6$ & $39,5 \pm 5,3$ \\
\hline
\end{tabular}

\section{BÀN LUẬN}

Trong nghiên cứu của chúng tôi, tuổi trung bình của người bệnh là 44.8 , như vậy phần lớn người bệnh thuộc lứa tuổi trung niên. Nhóm bệnh kén khí phổi đơn thuần có độ tuổi trung bình là $38,3 \pm 16,3$ và nhóm bệnh kén khí phổi kèm khí phế thũng là $57,1 \pm 10,9$ (bảng 3.1).
Tỉ lệ nam giới chiếm $83,5 \%$, nữ giới chiếm $16,5 \%$, với tỉ lệ nam : nữ là $5: 1$ cho thấy bệnh kén khí phổi thường xuất hiện ở nam giới hơn nữ giới.

Trong quá trình nghiên cứu, khi khai thác tiền sử bệnh của các trường hợp kén khí phổi, chúng tôi thấy phần lớn người bệnh có tiền sử hút thuốc lá, đặc biệt ở người bệnh là nam giới, ở cả 
hai nhóm nghiên cứu chiếm tỉ lệ $58,3 \%$ sau đó là tiền sử tràn khí màng phổi, $\mathrm{COPD}$, lao phổi, bệnh tim mạch và bệnh tiểu đường.

Nghiên cứu của Nguyễn Công Minh có $62 \%$ người bệnh có tiền sử hút thuốc lá, Pradheep Krisnamohan có $86 \%$ người bệnh có tiền sử hút thuốc lá, tác giả Paul H. Schipper có $98 \%$ tiền sử hút thuốc lá, còn tác giả Marco Mura lại có đến $100 \%$ người bệnh có tiền sử hút thuốc lá [1],[10],[12],[13] .

Bảng 2, xét chung cho cả hai nhóm kén khí, cho thấy phần lớn người bệnh có triệu chứng đau ngực chiếm tỉ lệ 95,1\% cho cả hai nhóm nghiên cứu, kế tiếp là khó thở chiếm $89,3 \%$, đang có ống dẫn lưu màng phổi $65 \%$, ho đàm chiếm $34 \%$, ít nhất là ho khạc máu có tỉ lệ $1 \%$.

- Triệu chứng đau ngực tuy chiếm tỉ lệ cao, nhưng trong đó thường là chỉ đau ngực ít

( $91,2 \%)$ chủ yếu do người bệnh than phiền, đau ngực nhiều chỉ chiếm 3,8\%.

- Có 1 trường hợp ho máu (1\%) do có tình trạng chảy máu trong kén khí gây ho khạc máu, bệnh cảnh này hiếm gặp nhất trong các bệnh cảnh của kén khí phổi, đây cũng là một trong những chỉ định phẫu thuật cho người bệnh kén khí phổi.

- Tình trạng ho khạc đàm là biểu hiện thường gặp trong những người bệnh có bệnh phổi mạn tính, chúng ta thấy phần lớn người bệnh có triệu chứng này trong nhóm kén khí có kèm khí phế thũng có $77,8 \%$, còn nhóm kén khí đơn thuần chỉ có $10,5 \%$ các trường hợp.

Như vậy, trong các biểu hiện lâm sàng, so sánh giữa hai nhóm bệnh kén khí ta thấy, tình trạng đau ngực nhiều thường chỉ thấy ở kén khí đơn thuần vì nhóm bệnh này có thể xuất hiện kén khí đơn độc có kích thước phát triển to, còn nhóm kén khí kèm khí phế thũng thường có những kén khí nhỏ và có ở nhiều thùy phổi. Ngoài ra, nhóm kén khí kèm khí phế thũng thường có tình trạng ho khạc đàm nhiều hơn nhóm kén khí đơn thuần.

Đánh giá độ khó thở trên lâm sàng, dựa trên bảng đánh giá theo mMRC:

- Nhóm kén khí đơn thuần, phần lớn có điểm khó thở từ 1 điểm trở xuống.

- Nhóm bệnh kén khí kèm khí phế thũng, có tình trạng khó thở nhiều hơn nhóm kén khí đơn thuần, phần lớn có điểm khó thở $\geq 1$.

Ảnh hưởng của bệnh lý kén khí phổi đến sức khỏe người bệnh được đánh giá qua sự thay đổi các chức năng hô hấp, trong đó bao gồm ảnh hưởng đến chức năng thông khí của phổi và nhưng thay đổi trong khí máu động mạch của người bệnh.

Kết quả nghiên cứu trong bảng 3 , nhìn chung cho cả hai nhóm kén khí trong nghiên cứu, phần lớn các trường hợp đều có mức FEV1 trong khoảng $50 \%$ đến $80 \%$ so tiên đoán chiếm $52,9 \%$. Thông khí với chỉ số FEV1 ở mức 30\% đến 50\% so tiên đoán chiếm $35,3 \%$. Còn lại có chỉ số FEV1 trên $80 \%$ so tiên đoán chiếm $11,8 \%$. Không có trường hợp nào có chỉ số FEV1 dưới $30 \%$, vì những trường hợp đó không có chỉ định phẫu thuật, cần có những điều trị nội khoa để ổn định tình trạng hô hấp.

Nhóm bệnh kén khí đơn thuần có chỉ số FEV1 trước phẫu thuật tập trung ở nhóm bệnh có $50 \%<\mathrm{FEV} 1<80 \%$ chiếm $58,3 \%$ các trường hợp.

Nhóm kén khí kèm khí phế thũng có mức độ giảm FEV1 nặng hơn nhóm kén khí đơn thuần, có $40 \%$ các trường hợp kén khí phổi kèm khí phế thũng có chỉ số FEV1 trong khoảng $50 \%$ đến $<80 \%$, còn lại FEV1 nhỏ hơn $50 \%$ so tiên đoán chiếm $60 \%$ các trường hợp. Như vậy, ta thấy nhóm kén khí phế thũng do ảnh hưởng của bệnh phổi mạn tính nên chỉ số FEV1 bị giảm nhiều hơn nhóm kén khí đơn thuần.

Đánh giá mức độ tắc nghẽn khi xét chỉ số FEV1/FVC ta có : Nhóm kén khí kèm khí phế 
thũng chỉ có $20 \%$ các trường hợp FEV1/FVC > $70 \%$ không có tình trạng tắc nghẽn hô hấp. Trong khi, các trường hợp FEV1/FVC < 70\% có dấu hiệu tắc nghẽn hô hấp cao chiếm $80 \%$ các trường hợp, các trường hợp này có mức tắc nghẽn từ trung bình đến nặng với FEV1 từ khoàng $50 \%$ đến $<80 \%$ so tiên đoán.

Các trường hợp được đánh giá có tình trạng tắc nghẽn về hô hấp, đều được chúng tôi hội chẩn và kết hợp điều trị với các bác sĩ chuyên khoa hô hấp của bệnh viện, để có thể kiểm soát tốt người bệnh trong quá trình điều trị trước phẫu thuật, sau phẫu thuật và cả việc hẹn tái khám ở cả 2 phòng khám chuyên khoa ngoại lồng ngực và chuyên khoa nội hô hấp sau khi người bệnh xuất viện.

Rối loạn hô hấp do tình trạng giảm oxy trong máu động mạch của bệnh kén khí phổi có thể làm giảm việc khuếch tán oxy qua màng phế nang mao mạch và làm bất tương xứng giữa thông khí và tưới máu.

Kết quả cho thấy, chỉ số $\mathrm{PaO} 2$ đạt trên 80 mmHg chiếm $36.2 \%$ tính chung cả hai nhóm, có chỉ số $\mathrm{PaO}_{2}$ giảm nhẹ chiếm $49,3 \%$ và $\mathrm{PaO}_{2}$ giảm trung bình chiếm $14,5 \%$ trong cả hai nhóm, không có trường hợp giảm $\mathrm{PaO}_{2}$ mức độ nặng.

Trong đó, nhóm kén khí đơn thuần có 20 trường hợp có $\mathrm{PaO} 2$ trên $80 \mathrm{mmHg}$ chiếm 48,8\% trong nhóm, có 16 trường hợp (39\% trong nhóm) $\mathrm{PaO} 2$ giảm nhẹ, và 5 trường hợp (chiếm 12,2\% trong nhóm) có $\mathrm{PaO}_{2}$ giảm mức trung bình.

Nhóm kén khí kèm khí phế thũng có 5 trường hợp $(17,9 \%)$ có $\mathrm{PaO} 2$ bình thường, có 18 trường hợp (chiếm 64,3\% trong nhóm) $\mathrm{PaO}_{2}$ giảm nhẹ và 5 trường hợp (chiếm $17.9 \%$ ) có $\mathrm{PaO}_{2}$ giảm mức trung bình.

Như vậy, phần lớn nhóm kén khí kèm khí phế thũng có tình trạng giảm $\mathrm{PaO} 2$ nhẹ đến trung bình, còn nhóm kén khí đơn thuần phần lớn lại có mức $\mathrm{PaO} 2$ bình thường.

\section{KẾT LUẬN}

Qua nghiên cứu 103 trường hợp kén khí được phẫu thuật, chúng tôi thấy kén khí phổi thường xuất hiện ở người bệnh nam giới trung niên, các đặc điểm lâm sàng thường gặp là đau ngực và khó thở, trong đó khó thở là biểu hiện thường gặp ở nhóm kén khí phổi có kèm khí phế thũng.

Những thay đổi chức năng hô hấp của người bệnh kén khí phổi, cho thấy kén khí gây ảnh hưởng đến sức khỏe người bệnh, phẫu thuật xử trí kén khí góp phần nâng cao chất lương cuôc sống cho người bệnh kén khí phổi.

\section{TÀI LIỆU THAM KHẢO}

1. Nguyễn Công Minh (2010), "Đánh giá kết quả điều trị ngoại khoa bệnh kén khí phổi tại bệnh viện Chợ Rẫy trong 10 năm (19992008)". Y Học TP. Hồ Chí Minh, 14 (2).

2. Trần Hoàng Thành (2006), " Bệnh phổi tắc nghẽn mạn tính". Nhà Xuất Bản Y Học Hà Nội, pp. 35-47.

3. Berdine G. (2013), "Bullous Lung disease". The Southwest Respiratory and Critical Care Chronicles, 1 (2).

4. Brokaw E.J. (2014), "Bullous emphysema - an incidental observation during dissection". International Journal of Anatomical Variations, 7, pp. 65-7.

5. Chandra D., Rose S.R. (2008), "Fluidcontaining emphysematous bullae: a spectrum of illness". European Respiratory Journal, 32, pp. 303-6.

6. Fernando J. Martinez (2015), "Bullous Disease of the Lung", Fishman's Pulmonary Diseases and Disorders". chapter 52, pp. 787-99.

7. Fujino N., Kubo H., Suzuki T., Ota C. (2011), "Isolation of alveolar epithelial type II progenitor cells from adult human lungs". Laboratory Investigation, 91, pp. 363-78. 
8. Gelabert C. (2015), "Bleb Point: Mimicker of Pneumothorax in Bullous Lung Disease". Western Journal Emergency Medicine,, 16 (3), pp. 447-9.

9. Goldberg C. (2013), "Bullous Lung Disease". Western Journal Emergency Medicine,, 14 (5), pp. 450-1.

10. Krishnamohen P. (2014), "Bullectomy for Symptomatic or Complicated Giant Lung Bulla". Annals of Thoracic Surgery, 97, pp. 425-31.

11. Munje R. (2016), "Secondary Spontaneous Pneumothorax: Bullous Emphysema or Bullous lung Disease". Vidarbha Journal of
Internal Medicine, 21, pp. 40-2.

12. Mura M. (2005), "Bullous emphysema versus diffuse emphysema: a functional and radiologic comparison". Respiratory Medicine, 99, pp. 171-8.

13. Schipper P. H. (2004), "Outcomes after resection of giant emphysematous bullae". Annals of Thoracic Surgery, 78, pp. 976-82. 